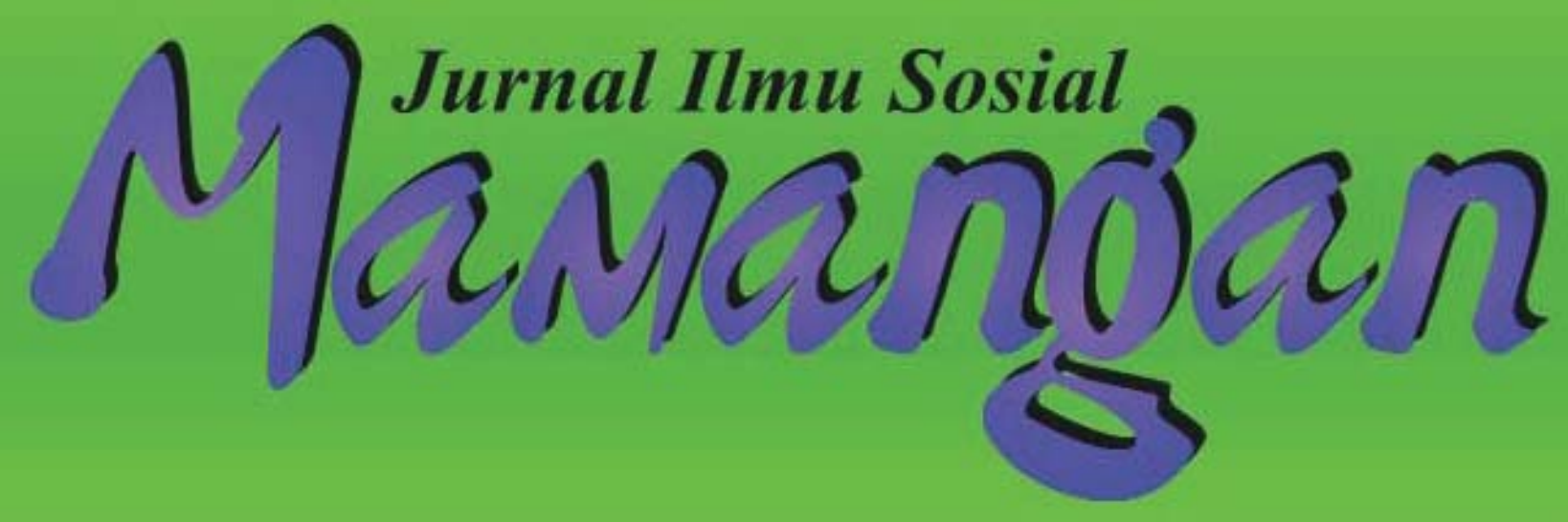

Beberapa Hipotesis Tentang Eksklusi Sosial di Indonesia Robert M.Z. Lawang

Dapatkah Indonesia Bebas Dari Kutukan Kolonial?

Refleksi Kritis Atas MP3EI

Noer Fauzi Rachman \& Dian Yanuardy

Rontoknya Dominasi Negara di Tambang Batu Bara Ombilin Sawahlunto

Zaiyardam Zubir \& Zulqayyim

Protes Korban Bencana; Studi Konflik Penanggulangan Bencana di Pasar Raya Padang

Firdaus

Peran Perempuan dalam Resolusi Konflik Rehabilitasi dan Rekonstruksi Pasar Raya Padang Ira Ariesta

Resolusi Konflik Berbasis Adat; Studi Resolusi Konflik Harta Pusaka Tinggi di Nagari Gantuang Ciri, Kab. Solok, Sumatera Barat

Yuhelna

Nelayan Vs Rentenir; Studi Ketergantungan Nelayan terhadap Rentenir pada Masyarakat Pesisir Delmira Syafrini 


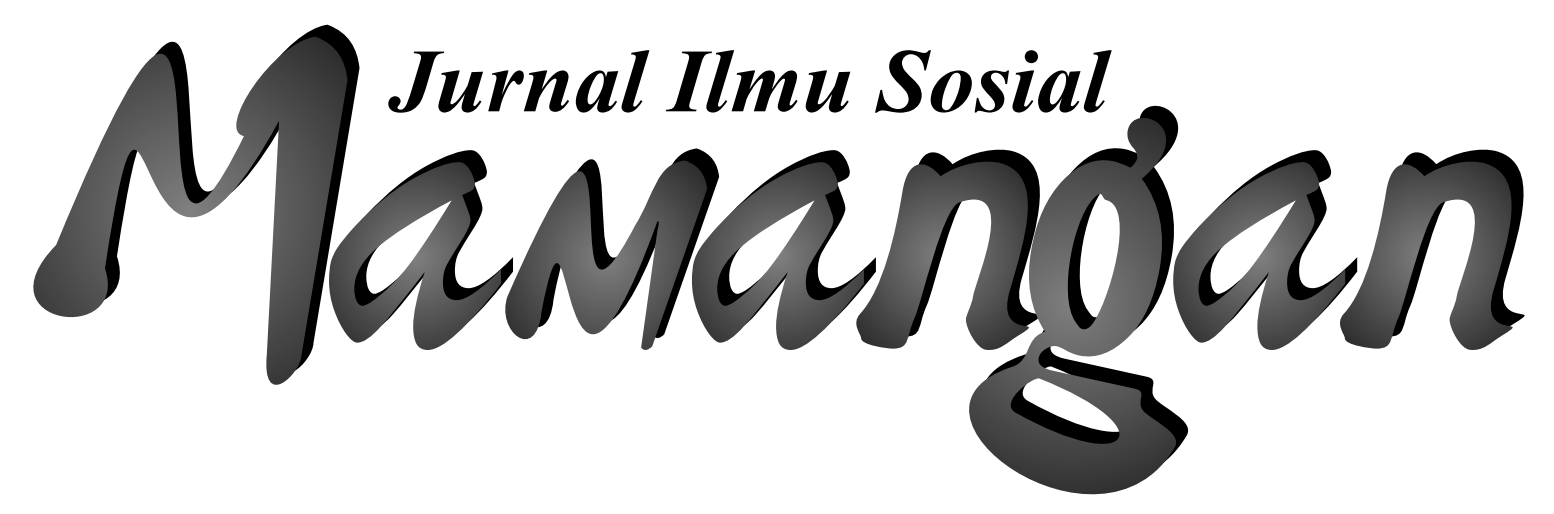




\section{Mitra Bestari}

Prof. Dr. Afrizal, MA. (FISIP, Unand Padang)

Prof. Dr. Badaruddin, M. Si. (FISIP, USU Medan)

Dr. A. Latief Wiyata, M. Si. (Universitas Jember, Jember)

Dr. Fikarwin Zuska, M. Si. (FISIP, USU Medan)

Nurus Shalihin, M. Si., Ph.D. (Fak. Ushuluddin IAIN Imam Bonjol Padang)

Dr. Semiarto A. Purwanto, M. Si. (FISIP, UI Jakarta)

Dr. Wahyu Wibowo, M. Si. (Universitas Nasional, Jakarta)

\section{Dewan Redaksi}

Dr. Zusmelia, M. Si.

Dr. Maihasni, M. Si.

Firdaus, S. Sos., M. Si.

\section{Pemimpin Redaksi/Editor}

Firdaus, S. Sos., M. Si.

\section{Anggota Redaksi}

Dian Kurnia Anggreta, S. Sos., M. Si.

Rinel Fitlayeni, S. Sos., MA.

Rio Tutri, M. Si

Sri Rahayu, M. Pd

Surya Prahara, SH,. MH.

Yuhelna, MA.

ISSN: 2301-8496

viii +81 halaman, $21 \times 29 \mathrm{~cm}$

\section{Alamat Redaksi:}

Laboratorium Program Studi Pendidikan Sosiologi, STKIP PGRI Sumbar Kampus STKIP PGRI, Jl. Gunung Pangilun, Padang, Sumatera Barat

Email: redaksimamangan@yahoo.com \& daus_gila@yahoo.com

\section{Penerbit:}

Laboratorium Program Studi Pendidikan Sosiologi, STKIP PGRI Sumbar

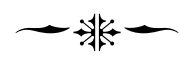




\section{PENGANTAR REDAKSI}

K onflik dalam masyarakat merupakan keniscayaan. Ia akan terus menjadi bagian dalam dinamika kemasyarakatan dan mengejawantah dalam berbagai bentuk yang secara garis bersar dikategorikan sebagai bentuk laten dan bentuk manifest. Pola dan bentuk konflik juga terus mengalami perkembangan sesuai dengan tingkat perkembangan masyarakat dimana konflik tersebut ada. Pola dan bentuk itu, mulai dari yang sederhana hingga yang paling 'canggih' dan bahkan disengaja ada untuk kepentingan tertentu oleh kelompok tertentu.

Meskipun para penganut fungsionalisme meganggap bahwa konflik dalam kehidupan sosial adalah abnormal (Johnson, 1994:161), namun konflik di lain kesempatan merupakan fakta sosial yang bisa fungsional bagi struktur tertentu selama ia dikelola dengan baik. Maka konflik kemudian di beberapa kesempatan juga dibutuhkan untuk kepentingan-kepentingan tertentu. Sehingga dengan demikian, adakalanya konflik mengikuti polanya sendiri dan adakalanya seirama dengan perkembangan masyarakat.

Menyadari bahwa perkembangan masyarakat terus melaju ke bentuk yang lebih kompleks, dan asumsi bahwa konflik juga akan kompleks sesuai dengan perkembangan kompleksitas masyarakat, Mamangan Edisi II yang ada di tangan pembaca ini mengambil konflik sebagai tema umum. Dalam edisi ini konflik dilihat oleh penulis dalam berbagai dimensi melalui berbagai pendekatan, baik secara teoritis maupun empiris melalui studi lapangan. Beberapa pakar di bisangnya telah menyumbang dalam dalam edisi kedua ini.

Tulisan pertama disumbangkan oleh Prof. Robert Lawang yang mendiskusikan konsep eksklusi sosial dalam konteks sosial, ekonomi dan politik. Tiga ranah ini menurut Lawang dikuasai arus utama (main stream) yang tidak mudah dimasuki oleh kelompok sosial tertentu dalam masyarakat paling bawah (underclass), sehingga mereka mengalami deprivasi. Selain itu, Lawang juga menyebut adanya perbedaan pandangan dan cara menjelaskan gejala sosial yang terkait eksklusi sosial. Meskipun konsep eksklusi sosial adalah konsep Barat, namun di Indonesia menurut Lawang, eksklusi sosial terjadi dalam berbagai struktur sosial masyarakat, baik di perkotaan maupun di pedesaan. 
Tulisan kedua disumbangkan oleh Noer Fauzi Rachman dan Dian Yanuardy yang mengupas secara kritis MP3EI. Dalam tulisannya, Fauzi dan Dian mempreteli skema MP3EI dan menyebutnya sebagai bagian dari upaya untuk memperdalam integrasi tanah air Indonesia ke dalam zona perdagangan bebas ASEAN dan Asia Timur. menurut mereka MP3EI pada pokoknya bertumpu pada upaya untuk melakukan reorganisasi ruang dalam rangka memperlancar interaksi dan aliran kapital, barang dan tenaga kerja untuk aktivitas produksi-konsumsi. Skema MP3EI dalam pola pemberian lisensi pada perusahaan untuk mengeksploitasi Sumber daya Alam menurutnya tidak jauh berbeda dengan kebijakan pemerintah kolonial Belanda sejak 1870, yang menempatkan Indonesia sebagai tempat produksi komoditas global.

Tulisan ketiga disumbangkan oleh Zayardam Zuber dan Zulqayim tentang rontoknya dominasi negara di Tambang Batubara Omblin, Sawahlunto. Zayardam dan Zulqayim dalam tulisannya mengemas sejarah beralihnya tambang di Kota Sawahlunto dari tangan perusahaan ke tangan rakyat yang selama puluhan tahun hanya menjadi penonton di arena tambang. Proses peralihan tersebut menurut Zayardan dan Zulqayim antara lain dilatari oleh penguasaan terhadap lahan di sekitar tambang yang dikuasi oleh dua kelompok, yaitu masyarakat adat dan pemerintah daerah. Selain itu, menurunnya aktivitas tambang PT. BA-UPO selaku BUMN yang kemudian menyerahkan pengurusan tambang kepada Pemda setempat juga menjadi bagian dari latar rontokya dominasi negara.

Tulisan keempat disumbangkan oleh Firdaus yang menguraikan protes korban bencana dalam proses rehabilitasi dan rekonstruksi di Pasar Raya Padang. Firdaus menyebutkan faktor penyebab munculnya protes adalah kebijakan pembangunan yang tidak partisipatif dan merugikan pedagang yang merupakan korban bencana. Kebijakan itu dibuat oleh pemerintah melalui mekanisme yang tidak sesuai dengan aturan yang ada. Protes yang dilakukan oleh korban bencana dilakukan dengan berbagai strategi, mulai dari strategi konfrontasi hingga negosiasi.

Tulisan kelima disumbangkan oleh Ira Ariesta yang mengulas peran perempuan dalam resolusi konflik Pasar Raya Padang. Ulasan Ira 'nyambung' dengan tulisan Firdaus sebelumnya. Jika Firdaus lebih menekankan pembahasan tentang penyebab dan strategi protes, maka Ira lebih menekankan pada resolusi konflik. Resolusi konflik yang dibahas Ira lebih fokus lagi pada peran perempuan. Menurut Ira, peran perempuan dalam proses resolusi konflik di Pasar Raya dilakukan oleh empat aktor utama, yaitu perempuan dari instansi pemerintah, perempuan aktivis LSM (PBHI Sumbar), perempuan aktivis mahasiswa dan perempuan pedagang. Keempat kelompok memainkan peran yang berbeda dalam resolusi konflik, mulai dari aksi massa hingga kegiatan advokasi terorganisir.

Tulisan keenam disumbangkan oleh Yuhelna yang membahas tentang mekanisme penyelesaian konflik harta pusaka tinggi secara adat di Minangkabau. Penyelesaian konflik harta pusaka tinggi di Minangkabau dilihat di nagari Gantuang Ciri. Resolusi konflik dilakukan pada 3 tingkatan. Tingkatan pertama resolusi konflik dilakukan di tingkat suku dengan melibatkan pangulu suku. Tingkat kedua resolusi konflik dilakukan pada tingkat yang lebih luas, yaitu pada institusi Tigo Niniak atau Ampek Niniak. Pada tingkat ini, resolusi konflik difasilitasi oleh niniak mamak masing-masing suku atau kaum yang berkonflik. Pada tingkat ketiga resolusi konflik dilakukan di lembaga adat Kerapatan Adat Nagari (KAN). Resolusi konflik pada tingkat ini difasilitasi oleh pengurus KAN yang merupakan perwakilan dari semua suku yang ada dalam nagari.

Tulisan terakhir, disumbangkan oleh Delmira Syafrini yang menganalisis ketergantungan nelayan dengan tengkulak di wilayah pesisir. Delmira melihat ketergantungan nelayan terhadap rentenir sebagai fenomena yang dilematis. Di satu sisi, nelayan mendapat kemudahan mengakses 
modal, di sisi lain nelayan dirugikan dengan suku bunga yang tinggi. Sementara, lembaga keuangan seperti Bank belum mampu menjadi katup penyelamat karena mekanisme rungguhan yang disyaratkan lembaga ini tidak terjangkau oleh nelayan. Di bagian akhir, Delmira menawarkan pemberdayaan sebagai solusi untuk memutus ketergantungan nelayan terhadap rentenir.

Demikianlah tulisan pada edisi ini, dan kepada para penyumbang tulisan pada edisi ini redaksi mengucapkan terima kasih atas karya intelektual dan buah pemikiran mereka, dan kepada para pembaca, redaksi mengucapkan selamat membaca. 



\section{DAFTAR ISI}

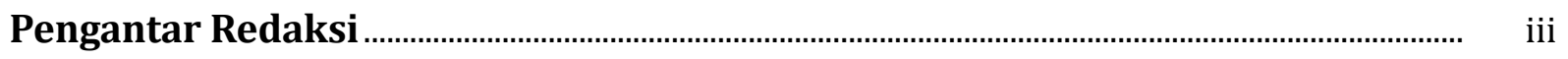

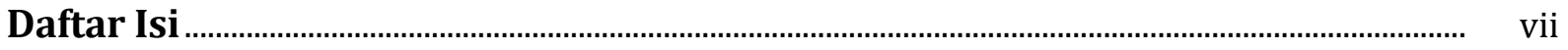

Beberapa Hipotesis Tentang Eksklusi Sosial di Indonesia

Robert M.Z. Lawang

Dapatkah Indonesia Bebas Dari Kutukan Kolonial?

Refleksi Kritis Atas MP3EI

Noer Fauzi Rachman \& Dian Yanuardy

Rontoknya Dominasi Negara di Tambang Batu Bara Ombilin Sawahlunto

Zaiyardam Zubir \& Zulqayyim

Protes Korban Bencana; Studi Konflik Penanggulangan Bencana di

Pasar Raya Padang

Firdaus

Peran Perempuan dalam Resolusi Konflik Rehabilitasi dan Rekonstruksi

Pasar Raya Padang

Ira Ariesta

Resolusi Konflik Berbasis Adat; Studi Resolusi Konflik Harta Pusaka Tinggi di Nagari Gantuang Ciri, Kab. Solok, Sumatera Barat

Yuhelna

Nelayan Vs Rentenir; Studi Ketergantungan Nelayan terhadap Rentenir pada Masyarakat Pesisir

Delmira Syafrini .

Profil Penulis. 



\title{
PERAN PEREMPUAN DALAM RESOLUSI KONFLIK REHABILITASI DAN REKONSTRUKSI PASAR RAYA PADANG
}

\author{
Ira Ariesta \\ (Sekretaris Eksekutif Qatar Charity Indonesia) \\ 一非-
}

\begin{abstract}
The active role of women in the process of conflict resolution expected on resulting policy with gender perspective and accelerate the process of peace. In reality, women have limited participation in the conflict resolution process, so it will result the bias gender policy and not in favour of women interest. Matrilineal cultural system is not asure that women have more power in the eforts of peace. For example is the case of rehabilitation and reconstruction conflict at Pasar Raya Padang after September 30 2009 earthquake. This paper explain the role of women in the contex of Minang kabau matrilineal cultural system in the conflict resolution process at Pasar Raya Padang rehabilitation and reconstruction. This paper describe participation, the strength and weakness of women, and the meaning of matrilineal culture for the role of women in the process of conflict resolution.
\end{abstract}

Kata kunci: Perempuan, Resolusi Konflik, Rehabilitasi \& Rekonstruksi.

\section{Pendahuluan}

Dalam proses resolusi konflik, keterlibatan perempuan perlu diutamakan bukan hanya untuk kepentingan pembangunan berbasis gender yang berujung pada kepentingan perempuan saja, namun juga diharapkan untuk melancarkan upaya perdamaian. Dengan adanya peran perempuan dalam upaya resolusi konflik diharapkan konflik juga cepat diatasi dan memiliki perspektif yang berkeadilan gender.

Masyarakat Kota Padang merupakan masyarakat Minangkabau yang memiliki sistem
Matrilineal, dimana garis keturunan keluarga berdasarkan garis keturunan ibu. Sistem Matrilineal dilihat sebagai sebuah pengakuan budaya akan keutamaan perempuan, maka lazimnya budaya ini memberikan keleluasaan dalam meningkatkan peran perempuan dalam berbagai upaya perdamaian. Dibandingkan sistem patrilineal, budaya dengan sistem ini lazimnya memberikan kemudahan perempuan untuk berperan lebih aktif dalam berbagai upaya resolusi konflik dan memperjuangkan kepentingannya. Dampak dari keterlibatan aktif peran perempuan dalam berbagai upaya resolusi 
konflik diharapkan menghasilkan perdamaian yang cepat diwujudkan.

Namun kenyataannya proses resolusi konflik dalam pembangunan pasca bencana gempa Sumbar 2009 di Pasar Raya Padang berlangsung sangat alot, bahkan sampai saat tulisan ini ditulis. Proses resolusi konflik yang didominasi oleh keterwakilan pedagang laki-laki berpotensi menghasilkan kebijakan yang tidak sesuai dengan kepentingan perempuan. Padahal peran perempuanlah yang paling diharapkan berperan sangat aktif untuk memperjuangkan kepentingannya dan menciptakan perdamaian apalagi pada ranah budaya sistem Matrilineal. Maka fenomena sosial ini menjadi menarik untuk dikaji. Peran perempuan dalam proses resolusi konflik rehabilitasi dan rekonstruksi Pasar Raya Padang ini perlu dilihat lebih mendalam untuk menjawab tendensi yang terjadi.

\section{Tinjauan Pustaka}

Studi mengenai peran perempuan dalam resolusi konflik bukanlah hal yang baru. Beberapa hasil penelitian tentang studi konflik memperlihatkan peran perempuan dalam konflik dan kontribusi perempuan dalam mewujudkan upaya perdamaian.Penelitian Sri Ratna Lampong (2008) tentang Peran Perempuan dalam Resolusi Konflik di Maluku menguraikan peran aktifis perempuan dalam mengupayakan perdamaian dalam konflik etnis yang terjadi di Maluku. Dengan menggunakan konsep resolusi konflik, peran dan resolusi konflik berbasis gender, Lampong menemukan perempuan yang berperan umumnya berasal dari instansi Lembaga Swadaya Masyarakat (LSM) melalui kegiatan advokasi yang berhubungan dengan upaya penghentian konflik.

Penelitian lainnya terangkum pada laporan penelitian LIPI (Lembaga Ilmu Pengetahuan Indonesia) bekerja sama dengan Centre for Humanitarian Dialogue (HD Centre) tentang peran perempuan dalam resolusi konflik Maluku dan Papua. Dalam rangkuman penelitian ini diungkapkan bahwa ibu rumah tangga di Maluku lebih berani menghadapi konflik (dengan tetap pergi ke pasar) karena peran mereka menjadi seorang ibu yang harus memenuhi kebutuhan keluarga. Identitas seorang ibu yang persuasif juga membantu proses rekonsiliasi konflik karena masyarakat lebih merasa nyaman berkomunikasi dengan pola ini. Tantangan yang dihadapi oleh perempuan Maluku dalam proses resolusi konflik adalah, bahwa perempuan tidak mendapat tempat untuk berpartisipasi di tingkat formal. Sedangkan di Papua, tantangan peran perempuan adalah nilai budaya patriarkhi sangat kuat. Namun, nilai budaya di Papua menjadikan perempuan sebagai simbol perdamaian dan hal ini menjadikan posisi mereka strategis sebagai mediator yang dipercaya.

Kajian tentang peran perempuan dalam upaya perdamaian juga pernah ditulis oleh Ekna Satriyati (2008) dalam Satriyati menulis peran perempuan dalam upaya perdamaian pada konflik yang terjadi antara etnis Dayak dan Madura. Salah satu agen perdamaian dalam konflik ini dikenal dengan sebutan DARA ARUM yaitu sebuah komunitas perempuan di Banjarmasin yang memperhatikan persoalan-persoalan seperti multikulturalisme, kepercayaan, kebersamaan dan kejujuran. Strategi yang dilakukan DARA ARUM yaitu memperkuat keahlian dalam membangun interaksi sosial untuk mewujudkan aksi kolektif. Perjuangan kolektif inilah yang akan mengembangkan sumber daya komunitasnya untuk menciptakan perdamaian. Selain itu DARA ARUM juga membangun kepercayaan antar etnis dengan cara mengunjungi untuk mempromosikan upayaupaya rekonsiliasi. Strategi ketiga yang dilakukan DARA ARUM adalah dengan menjalankan tanggung jawab dengan cara meningkatkan kapasitas dan pemberdayaan kelompok perempuan dengan menonjolkan isu-isu kesetaraan gender.

Tiga penelitian di atas membahas isu konflik etnis (kultural) pada masyarakat patriarkhi. Tulisan ini membahas konflik struktural sumber daya yang bersifat ekonomi politik antara pemegang otoritas (pemerintah) dan bukan pemegang otoritas 
(pedagang) pada masyarakat Matrilineal.

Dalam konteks budaya Minangkabau sendiri beberapa penelitian juga pernah dilakukan. Antara lain penelitian Ranny Emilia tentang Konflik dan Perdamaian: Memperbaiki Dunia Melalui TanganTangan Perempuandan penelitian Jendrius tentang Keterlibatan Perempuan dalam Politik di Nagari.. Literatur ini menunjukan bahwa walaupun dalam sistem Matrilineal, peran perempuan masih saja tidak mendapat tempat secara substantif pada tingkatformal, namun peran mereka muncul bahkan dapat menentang sistem yang berkuasa pada saat itu jika memang mengganggu kepentingan mereka dan jika memang upaya-upaya bersama dapat dilakukan. Dua penelitian ini sama-sama membahas peran perempuan dalam ranah sistem Matrilineal baik dalam situasi konflik maupun dalam kebijakan politik. Namun, tidak ada yang membahas tentang peran perempuan dalam proses resolusi konflik kebijakan publik dalam level pemerintahan kota.

\section{Metode Penelitian}

Penelitian ini dilakukan berdasarkan pendekatan kualitatif karena penelitian ini menganalisis proses sosial dan aktor-aktor di dalamnya. Penelitian ini menggunakan model analisis studi kasus tunggal dengan Single Level Analysis, karena penelitian ini hanya akan melihat peran (yang termasuk di dalamnya perilaku dan tindakan) perempuan dengan fokus pada peran perempuan dalam kasus proses resolusi konflik rehabilitasi dan rekonstruksi Pasar Raya Padang saja.

Unit analisis penelitian ini adalah individu yang terlibat dalam proses resolusi konflik rehabilitasi dan rekonstruksi Pasar Raya Padang. Informan yang dibutuhkan sebagai sumber data merupakan individu (perempuan maupun lakilaki) yang berasal dari instansi yang terlibat dalam proses resolusi konflik Pasar Raya Padang. Jenis dan sumber data penelitian adalah data primer dan sekunder., Penelitian dilaksanakan di Kota Padang Sumatera Barat. Teknik pengumpulan data yang digunakan adalah wawancara mendalam, analisis dokumen dan diskusi kelompok terfokus. Data dianalisis dengan pendekatan Miles \& Hubermen, yaitu reduksi data, penyajian data dan penarikan kesimpulan.

\section{Peta dan Proses Resolusi Konflik.}

Isu utama dalam konflik rehabilitasi dan rekonstruksi Pasar Raya Padang adalah konfrontasi kepentingan antara pemegang otoritas dan kepentingan bukan pemegang otoritas. Berdasarkan analisis kepentingan ini maka dapat disimpulkan bahwa konflik ini bersifat materialistis. Pedagang menuntut perubahan kebijakan politik pemerintah yang merugikan mereka secara ekonomi. Di sisi lain, tuntutan pemerintah Kota Padang juga bersifat materialistis dimana pedagang diharapkan membayar harga kios yang ditetapkan jika pembangunan selesai dilakukan dan selalu berupaya mempertahankan status quo melalui alat negaranya. Secara garis besar maka dapat ditarik isu konflik adalah rehabilitasi dan rekonstruksi Pasar Raya Inpres II, III dan IV Kota Padang yang dapat dikategorikan sebagai konflik pembangunan. Aktor konflik selain aktor utama (pemerintah dan pedagang) adalah organisasi PBHI Sumbar, organisasi AMPEPARA, DPRD Kota Padang, FWK, dan Komnas HAM. Pemetaan aktor dan kepentingannya dapat dilihat pada gambar berikut ini:

Gambar 1.

Peta Konflik Rehabilitasi dan Rekonstruksi Pasar Raya Padang ${ }^{1}$

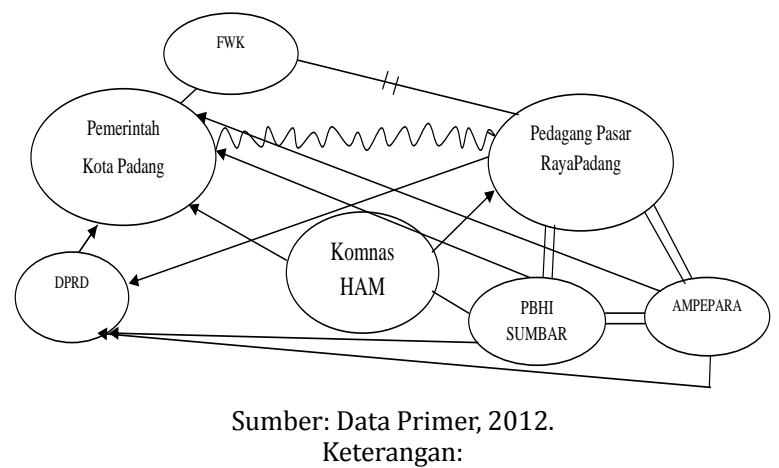

$m m$ = Konflik

$\ldots=$ Putusnya suatu hubungan

1. Bagan ini dibuat berdasarkan analisis pemetaan konflik Fisher dkk, 2001 
$\longrightarrow=$ Arah utama suatu pengaruh atau kegiatan

- = Hubungan yang agak dekat

$==$ Aliansi atau hubungan yang sangat dekat

Dinamika terjadinya konflik dimulai dari pra konflik pada awal masa tanggap darurat bencana gempa bumi yang terjadi pada akhir tahun 2009, dimana pemerintah kota berupaya mengembalikan produktivitas ekonomi Pasar Raya dengan mendirikan kios-kios darurat untuk pedagang. Pembangunan kios darurat ini justru berdampak pada menurunnya omzet penjualan pedagang. Konfrontasi terjadi dengan adanya wujud protes pedagang terhadap keputusan pemerintah yang hendak melakukan rekonstruksi Pasar Raya Padang. Masa krisis konflik terjadi pada pertengahan bulan Agustus 2011, ditandai dengan adanya bentrok antara pedagang dengan aparat keamanan yang akan melakukan pemagaran Pasar Raya sebagai awal proses rekonstruksi. Pada masa eskalasi ini konflik kekerasan muncul, hingga turunnya Komnas HAM sebagai mediator pada masa akibat konflik. Pasca konflik dijalankan setelah munculnya mediator dan upaya-upaya resolusi konflik dijalankan.

Gambar 2.

Tahap-Tahap Konflik Rehabilitasi dan Rekonstruksi Pasar Raya Padang

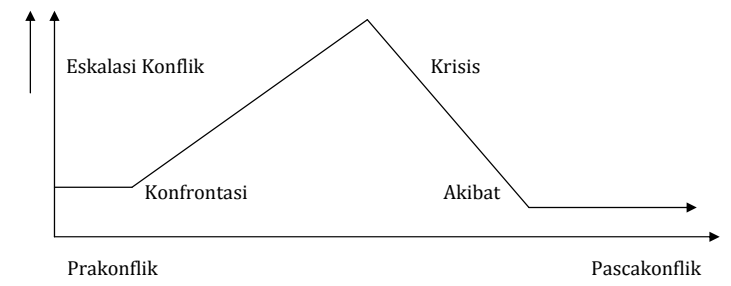

\footnotetext{
$2009 \quad 2010 \quad 2011$

Keterangan:

Pra Konflik : terjadi pada akhir 2009

Konfrontasi : terjadi dari akhir 2009 hingga pertengahan 2011

Krisis : : terjadi pada pertengahan 2011

Akibat : terjadi pada akhir 2011

Pascakonflik : terjadi pada akhir 2011
}

Sumber: Data Primer, 2012.

Proses resolusi konflik dilakukan dengan berbagai strategi. Awalnya mediasi dilakukan oleh berbagai pihak yang terlibat dengan bantuan Komnas HAM sebagai mediator. Namun mediasi tersebut gagal karena masing-masing pihak tidak menemukan solusi integratif yang memuaskan masing-masing kepentingan para pihak, seperti terlihat pada gambar berikut ini:

Gambar 3.

Proses Mediasi Konflik Rehabilitasi dan Rekonstruksi Pasar Raya Padang

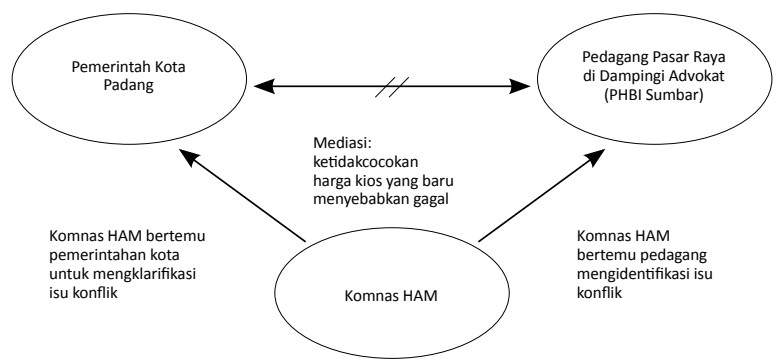

Sumber: Data Primer, 2012

Kesepakatan akhirnya muncul pada upaya negosiasi yang dilakukan antara pedagang dan pemerintah Kota Padang. Dengan adanya solusi integratif yang diterima masing-masing pihak yang mengutamakan logika ekonomi akhirnya kesepakatan tercapai. Pemerintah Kota Padang bersedia memberikan kios gratis kepada pedagang jika proses rekonstruksi selesai dilakukan namun pedagang berkewajiban membayar uang retribusi yang dinaikkan tarifnya.

Gambar 4.

Proses Negosiasi Konflik Rehabilitasi dan Rekonstruksi Pasar Raya Padang

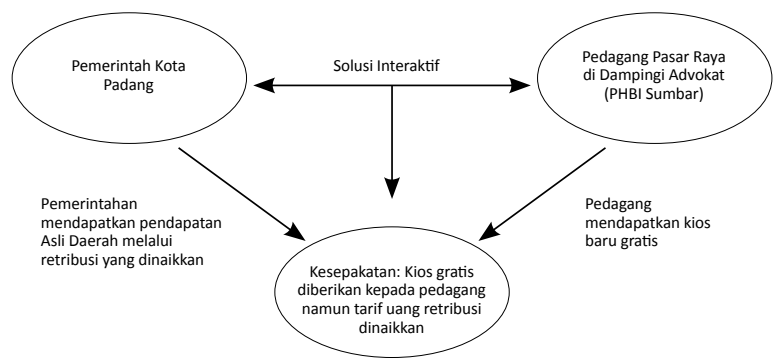

Sumber: Data Primer, 2012

\section{Peran Perempuan dalam Proses Resolusi Konflik.}

Aktor yang terlibat dalam proses resolusi konflik ini tidak terlepas dari peran mereka 
dalam sebuah sistem sosial dimana mereka berada. Aktor yang berperan dipengaruhi oleh struktur dimana ia berada. Intervensi yang dilakukan perempuan ini dengan demikian tidak terlepas dari peran mereka dalam posisi sistem sosial tertentu. Hal ini tentunya ikut mempengaruhi nilai dan norma dan berujung pada kepentingan dalam menjalankan peran mereka untuk mengambil bagian dari proses resolusi konflik ini.

Masing-masing aktor memiliki posisi yang berbeda sehingga mempengaruhi nilai dan norma yang diinternalisasikannya secara sadar menjadi kepentingan yang berbeda satu sama lain. Namun demikian ada beberapa kesamaan kepentingan yang dapat dilihat dari berbagai sudut pandang sifatnya. Kepentingan yang bersifat publik lebih ditekankan oleh aktor perempuan dari Dinas Pasar, PBHI Sumbar dan AMPEPARA. Sedangkan kepentingan privat (domestik) ditekankan oleh aktor perempuan dari Pedagang Pasar Raya Padang. Namun dari segi kepentingan dalam konteks konflik, PBHI Sumbar, AMPEPARA dan Pedagang Pasar Raya memiliki kepentingan yang sama yaitu merubah status quo, sedangkan kepentingan aktor perempuan dari Dinas Pasar adalah bertahannya status quo.

Tindakan yang dilakukan perempuan yang mewakili peran mereka dalam lembaga maupun institusi mereka sangat berbeda. Tindakan tersebut tidak terlepas lagi dari peran dan fungsinya dalam sistem sosialnya. Peran tersebut dapat dilihat dalam uraian di bawah ini:

\section{Peran Perempuan Dari Instansi}

\section{Pemerintah}

Perempuan di pemerintahan terutama berasal dari Dinas Pasar. Peran yang mereka lakukan terutama mengikuti setiap rapat yang diselenggarakan oleh Dinas Pasar. Namun, intervensinya dalam hal ini hanya sebagai notulis dalam rapat. Intervensi yang dilakukan perwakilan perempuan dari
Dinas Pasar berkisar pada kegiatan-kegiatan sosialisasi yang dilakukan pemerintah Kota Padang terkait dikarenakan tugas yang diamanatkan padanya menjadi notulis.

Selain itu, dalam pertemuan formal dimana yang hadir adalah perwakilan pemerintah Kota Padang yang memiliki posisi lebih tinggi dari mereka, mereka tidak ikut berbicara. Termasuk ketika Komnas HAM mendatangi Pemerintah Kota untuk meminta penjelasan mengenai kronologis pemagaran dan pembongkaran gedung Pasar Inpres II, III dan IV, perwakilan perempuan dari Dinas Pasar ini tidak ikut berbicara.
"Pada saat rapat, di saat itu kan ibu sebagai notulis, ibu ndak ngomong..... (Pada saat pertemuan Komnas HAM dengan Walikota tersebut) ibu nggak ada bicara soalnya itu sudah level nya kan udah Walikota kan.." (Wawancara dengan Hasna S.Sos M.Si, Kasi Perencanaan dan Evaluasi Dinas Pasar Raya Padang, tanggal 7 September 2012 di Kota Padang)

\section{Perempuan dari LSM}

Perempuan dari LSM terutama adalah aktivis dari PBHI (Perhimpunan Bantuan Hukum dan Hak Asasi Manusia Indonesia) Sumatera Barat. Perannya lebih banyak melakukan advokasi kepada kelompok pedagang agar pedagang dapat menyuarakan aspirasinya secara terorganisir. Selain itu aktivis ini juga melakukan pendampingan pada setiap rapat yang dilakukan antara pedagang dan pihak penengah seperti DPRD dan negosiasi dengan Pemerintah Kota sejak September 2011. Tindakan aktivis perempuan ini lebih kepada pendampingan pedagang dalam rapat dengar pendapat, memberikan pengetahuan-pengetahuan tentang aturan hukum kepada pedagang agar pedagang dapat menyuarakan aspirasi mereka dengan cara yang terorganisir dan diterima karena mengikuti prosedur hukum yang kuat. Tindakan aktivis ini adalah memberikan pengertian kepada 
pedagang, dengan cara mengumpulkan pedagang di Kantor PBHI Sumbar dan memberikan penjelasan apa saja hak-hak maupun kewajiban pedagang.

Berikut kutipan wawancara dengan aktivis perempuan PBHI Sumbar:

\begin{abstract}
"Tindakannya advokasi dan pendampingan yang kita lakukan mulai menjelaskan tentang posisi pedagang dalam hubungannya dengan Negara. Kita melakukan advokasi dalam konteks Negara, bagaimana hubungan rakyat dengan Negara. Apa yang menjadi kewajiban Negara, apa yang menjadi hak rakyat, apa yang hak dasar, apa yang tidak hak dasar. Apa itu yang hak asasi, mungkin sesuai dengan kemampuan, sesuai dengan keuangan. Jika hak dasar itu berlaku untuk siapa saja, tidak tergantung status lagi. Kita juga perlu sampaikan batas-batas hak ini, hak itu bukan sewenang-wenang, ada batasbatasnya. Misalnya, untuk berjualan, batas hak pedagang itu, sebatas haknya untuk bisa berjualan, di tempatyang strategis melakukan jual beli pula. Semena-mena sampai terganggu pedagang yang lain, itu tidak boleh. Kemudian dalam masalah ini kan acuannya rehab rekon, jadi acuannya Undang-undang bencana, di sana kita sampaikan ini yang korban.... Korban dalam konteks Undang-undang kebencanaan itu adalah siapapun yang terkena dampak, termasuk pedagang kaki lima, termasuk buruh, termasuk pedagang asongan. Siapapun yang terkena dampak gempa itu." (Wawancara dengan Suharyati, Koordinator Masalah Pasar Raya Padang PBHI Sumbar tanggal 15 September 2012 di Kota Padang)
\end{abstract}

Kegiatan pendampingan yang dilakukan aktivis perempuan ini mengikuti nilai-nilai yang dimiliki oleh lembaganya untuk membela hak-hak setiap orang secara berkeadilan. Sehingga tindakan yang ia lakukan pun merupakan tindakan yang disepakati oleh lembaga dan merupakan representasi dari lembaga dimana dia bernaung. Tindakan pendampingan dengan demikian tidak hanya dalam lingkungan antara lembaga dengan pedagang saja (internal) namun juga pendampingan ke instansi luar seperti DPRD. Dikarenakan tujuannya adalah pemberdayaan dalam jangka panjang, maka lembaga ini juga berupaya memberikan pendampingan kepada pedagang untuk berani bicara dan memperjuangkan haknya secara mandiri.

\section{Aktivis Perempuan dari Mahasiswa}

Aktifis perempuan yang berasal dari mahasiswa tergabung dalam kelompok taktis yang menamakan diri sebagai AMPEPARA (Aliansi Masyarakat Peduli Pasar Raya). Tindakan yang merfeka lakukan adalah secara kolektif seperti unjuk rasa, aksi damai ke DPRD, membuka ruang publik untuk melakukan advokasi serta berupaya memberikan pendidikan politik kepada pedagang Pasar Raya. Ia menjadi bahagian dari aksi kolektif yang dilakukan AMPEPARA.

Awal tindakannya adalah diskusi dengan kelompok yang berada di organisasinya. Diskusi ini juga melibatkan LSM dan LBH yang memiliki perhatian terhadap masalah Pasar Raya Padang. Diskusi ini bertujuan untuk memberi pemahaman kepada masing-masing anggota agar dapat melakukan intervensi dalam penyelesaian permasalahan Pasar Raya. Berdasarkan diskusi tersebut kemudian setiap anggota mendapatkan pemahaman tentang kebijakan-kebijakan pembangunan Pasar Raya. Aksi kemudian dilanjutkan dengan mencoba melakukan dialog dengan DPRD dan pemerintahan Kota. Namun, jika upaya ini tidak mendapat respon positif dari DPRD, maka aktivis ini melakukan demonstrasi.

\section{Pedagang Perempuan}

Pedagang Pasar Raya yang perempuan melakukan tindakan untuk tetap menjaga agar hak-haknya tidak dirampas oleh pihak yang sewenang-wenang. Perempuan-perempuan dari pedagang pasar raya melakukan aksi kolektif seperti; menghadang petugas keamanan agar proses pembongkaran dihentikan. Tindakan ini 
memang tidak diterima aparat keamanan karena perempuan yang melakukan tindakan ini justru mendapatkan kekerasan yang dilakukan pihak dari pemerintah Kota.

Berikut hasil wawancara salah satu pedagang yang perempuan:

\begin{abstract}
“...kami melakukan demo-demo itu ingin meminta ketentuan (kejelasan) kami saja. Oleh karena itulah kami ikut demo, ditolong oleh anak mahasiswa.... Tapi tiba-tiba datang pompa air dengan mobil pemadam kebakaran. Kami perempuan itu yang menghadang, jadi yang kena semprot ya perempuan, kena tarik tu perempuan. Kami berani menghadang karena kami memperjuangkan hak kami masing-masing dan kami sudah siap untuk mati seandainya mereka berbuat seperti itu, kami siap untuk menantang, apakah memang ada prikemanusiaan orang-orang itu tentu tidak mau mereka menentang perempuan, namanya ibu-ibu sudah tua kan. Ternyata tidak ada prikemanusiaannya, kami malah disemprot dengan air pemadam kebakaran tersebut. Ada yang diinjak-injak, ada yang dipukul tangannya, yang ibu (informan) kena tarik seperti anjing terus sampai ke ujung jalan." (Wawancara dengan Dahniar, Pedagang Pasar Raya Padang tanggal 29 September 2012 di Kota Padang)
\end{abstract}

Pedagang melakukan intervensi karena memiliki peran sebagai pencari nafkah dalam keluarga mereka. Harapannya untuk mempertahankan hak-hak kesejahteraan keluarganya justru membawa pedagang yang perempuan ini terlibat dalam penyelesaian konflik kebijakan yang bersifat ekonomi politik tersebut. Hal ini dapat dikuatkan oleh hasil wawancara dengan salah satu perwakilan perempuan yang bertindak dalam aksi kolektif berikut ini:

\footnotetext{
"Pada waktu itu muncul tindakan tersebut, daripada saya dan keluarga tidak makan. Ketika pemagaran akan dilakukan, sudah terbayang hal-hal yang buruk." (Wawancara dengan Cici, pedagang Pasar Raya Padang yang menjadi korban kekerasan, tanggal 29 September 2012 di Kota Padang.)
}

Tindakan yang dilakukan perempuan yang mewakili peran mereka dalam lembaga maupun institusi sangat berbeda. Jika aktivis PBHI Sumbar memilih tindakan yang lebih terorganisir, AMPEPARA dan pedagang Pasar
Raya Padang lebih memilih tindakan spontan secara kolektif untuk membangun sebuah gerakan yang diharapkan menuju perubahan. Perempuan dari pedagang Pasar Raya sangat aktif pada upaya resolusi konflik dalam hal aksi kolektif namun tidak dalam perundingan (baik negosiasi maupun mediasi). Dengan aksi kolektif yang mereka lakukan, mereka dapat dinyatakan berkontribusi besar akan terciptanya negosiasi dan mediasi tersebut walaupun untuk upaya negosiasi dan mediasi itu sendiri, mereka menyerahkan semuanya pada ketua perwakilan persatuan mereka yang merupakan laki-laki.

Masing-masing aktor ini memiliki kapasitas yang berbeda satu sama lain. Implikasinya adalah masing-masing aktor perempuan tersebut membangun relasi dan melancarkan strategi membangun interaksi sosial satu sama lain untuk saling melengkapi kapasitas bagi aktor-aktor yang memiliki satu kepentingan atau tujuan.

Walaupun sama-sama perempuan, tiap aktor memiliki hubungan relasi yang berbeda masing-masingnya didasarkan dari kepentingan dan posisi dimana ia berada. Dalam membangun relasi dalam proses resolusi konflik tersebut masing-masing pihak memiliki strategi untuk membangun interaksi sosial dengan caranya masing-masing. Jadi, strategi tiap aktor perempuan yang membangun interaksi tersebut merupakan strategi perempuan dalam proses resolusi konflik. Namun demikian strategi tersebut tidak selalu berjalan secara efektif.

Upaya aktor perempuan yang berperan dalam proses resolusi tidak selalu berjalan mulus. Tiap aktor memiliki hambatan dan dorongan masing-masing yang berkaitan dengan kondisi relasi antara satu pihak dengan pihak yang lain. Hambatan tersebut diantaranya kekerasan yang diterima oleh perempuan, serta sistem sosial yang diterapkan oleh masing-masing aktor. Sejauh ini manfaat hasil resolusi konflik masih sebatas kejelasan posisi pedagang oleh pedagang perempuan. 
Peran perempuan sebagai agen aktif terbatas pada konteks waktu terjadinya konflik. Pada saat krisis dalam tahap konflik, perempuan terutama pedagangyang perempuan yang awalnya pasif menjadi sangat berani melakukan tindakan represi dan subversi karena memiliki kepentingan untuk mempertahankan hak-hak mereka sebagai pedagang dengan melakukan tindakan-tindakan kolektif seperti menghadang aparat keamanan yang hendak melakukan pemagaran dan ikut melakukan unjuk rasa untuk merubah status quo dari kebijakan pemerintah. Perempuan dari PBHI Sumbar maupun AMPEPARA juga menjadi agen yang aktif ketika mendukung pedagang untuk melakukan upaya-upaya kolektif. Sedangkan perempuan dari Dinas Pasar tidak dapat dinyatakan sebagai agen yang aktif pada proses terjadinya konflik karena mengikuti struktur pemerintahan di mana ia berada.

Peran perempuan sebagai agen pada konteks terjadinya konflik sangat kontras dengan peran perempuan dalam proses resolusi konflik. Pada saat proses resolusi konflik, setiap aktor perempuan menjadi agen yang pasif karena tidak lagi memiliki kemampuan untuk menembus meja perundingan pada tahap mediasi maupun negosiasi. Proses negosiasi dan mediasi memerlukan wakil yang representatif sehingga diperlukan kemampuan yang baik untuk mencapai indikator perwakilan tersebut. Kapasitas kemudian sangat menentukan masing-masing setiap aktor perempuan untuk menjadi agen yang aktif.

Dengan demikian, peran perempuan sebagai agen cukup dinamis. Awalnya setiap aktor merupakan agen yang pasif dalam sistem sosial mereka, namun ketika kepentingan mereka terganggu oleh hal-hal yang bersifat eksternal seperti kebijakan pemerintah yang dinilai merugikan, perempuan menjadi agen aktif dengan melakukan tindakan kolektif sebagai wujud pertentangan terhadap kebijakan pemerintah. Namun kemudian aktor perempuan kembali menjadi agen yang pasif pada proses resolusi konflik karena tidak memiliki kemampuan atau kapasitas yang cukup dan berada di struktur yang membatasi mereka menjadi agen yang aktif pada proses resolusi konflik.

\section{Pengaruh Sistem Matrilineal dan Struktur Politik Demokrasi terhadap Peran Perempuan dalam Proses Resolusi Konflik.}

Penelitian ini membuktikan bahwa walaupun dalam konteks sistem Matrilineal, struktur politik patriarki diterapkan oleh pihak yang terlibat dalam proses resolusi konflik ini sehingga menghambat peran perempuan.

Peran perempuan dalam proses resolusi konflik terhambat karena berada pada konteks sistem Matrilineal yang bersanding dengan struktur politik patriarki. Penerapannya dapat dilihat dari tata cara pemilihan perwakilan pedagang untuk maju pada proses perundingan formal. Setiap pedagang (termasuk perempuan) memilih ketua organisasi yang merupakan lakilaki. Hal ini sangat sesuai dengan penerapan sistem kepemimpinan patriarki dalam budaya Minangkabau dimana setiap komunitas masyarakat dipimpin oleh seorang laki-laki. Struktur politik patriarki sangat jelas diterapkan terutama oleh pedagang perempuan meskipun dalam konteks sistem kekerabatan Matrilineal sehingga mempengaruhi minimnya peran perempuan dalam proses resolusi konflik.

Perempuan Minangkabau tidak cukup terlatih untuk berbicara di depan umum oleh sistem adat. Alasanya adalah struktur Minangkabau sendiri terbiasa mengutamakan suara penghulu, ninik mamak, dsb (posisi teratas dalam struktur adat) yang merupakan (bahkan harus) laki-laki untuk tampil di depan publik. Perempuan Minangkabau terbiasa untuk menyerahkan semua yang berhubungan dengan hal-hal di luar kekuasaan domestiknya kepada laki-laki, apalagi untuk berbicara di depan umum dalam forum yang formal. Adat terlalu 
membebani mereka dengan nilai-nilai "raso jo pareso" (rasa malu) sehingga mereka tidak cukup terlatih berbicara secara terorganisir di depan umum dimana yang dihadapi adalah laki-laki dan perempuan. Berikut kutipan wawancara dengan pemuka adat di LKAAM Kota Padang,

\begin{abstract}
" Saat ini kan sudah ada demokrasi, perempuan dan laki-laki memiliki hak yang sama seperti bekerja di sektor publik seperti jadi guru. Kadangkadang bukannya perempuan tidak mau untuk tampil mengurusi urusan publik, tapi mereka segan, jadi rasa malu mereka melebihi rasa malu laki-laki dan raso paresonya sangat tinggi... Bukannya mereka tidak memiliki kemampuan, mereka mampu sebenarnya untuk tampil.... Perempuan Minang biasanya lebih mendahulukan kepentingan suaminya (dalam sebuah forum), tapi kalau mereka berkumpul sama-sama perempuan baru mereka berani bicara. Selama ada suaminya, perempuan Minang tidak akan mau bicara kecuali memang kewajibannya bicara maka ia akan bicara walaupun ada suami di sebelahnya." (Diskusi dengan LKAAM Kota Padang, 3 Oktober 2012)
\end{abstract}

Sistem Matrilineal membebani perempuan dengan tanggung jawab ganda yang terlalu banyak, sebagai pencari nafkah (pengelola ekonomi keluarga) sekaligus ibu rumah tangga, sehingga waktu yang mereka punya tidak cukup memadai agar digunakan untuk penambahan pengetahuan tentang hukum dan urusan publik dan tidak dapat selalu berpatisipasi dalam pertemuan formal. Dampaknya, mereka tidak cukup memiliki kapasitas untuk terbiasa berperan dalam proses resolusi konflik yang diharapkan sangat teroganisir pada tingkat perundingan formal yang lebih tinggi. Selain itu, sistem Matrilineal tidak melepaskan perempuan dari penerapan sistem kepemimpinan dan politik patriarki sehingga dapat dinyatakan bahwa peran perempuan dalam proses resolusi konflik dalam konteks sistem matrilineal sangat minim karena berhubungan dengan kapasitas perempuan yang terbatas sebagai konsekuensi dari pengaturan peran perempuan dalam sistem Matrilineal dan penerapan struktur politik patriarki yang sangat kental.

Munculnya nilai-nilai demokrasi membuka peluang perempuan untuk berani kembali melakukan perlawanan terhadap kekuasaan yang sewenang-wenang. Dalam konteks penelitian ini adalah demonstrasi dan unjuk rasa yang dilakukan pedagang Pasar Raya Padang dan organisasi mahasiswa AMPEPARA. Aktivis perempuan dari PBHI Sumbar juga merupakan aktor yang merasakan dampak demokrasi dimana ia memiliki kesempatan yang sama dengan aktivis PBHI Sumbar yang lainnya untuk ikut melakukan perjuangan membela hakhak pedagang. Upaya seperti pendampingan pedagang pada rapat dengar pendapat dan pemberian pengetahuan serta informasi kepada pedagang sangat aktif dilakukannya. Organisasi PBHI Sumbar sebagai organisasi masyarakat sipil sendiri sangat terbuka memberikan kesempatan kepada aktivis perempuan ini untuk sama-sama memperjuangkan pedagang.

Walaupun demikian, struktur demokrasi ini tidak begitu dimanfaatkan oleh pedagang Pasar Raya sendiri. Peran perempuan dalam proses resolusi konflik dapat dikatakan tidak begitu memuaskan. Walaupun dalam situasi konflik perempuan dapat melakukan aksi-aksi kolektif melawan kebijakan pemerintah daerah, namun pada proses resolusi konflik perempuan tetap tidak dapat memiliki kemampuan menembus perundingan di tingkat formal sehingga harapan bahwa perempuan sebaiknya berkontribusi sebagai pembuat keputusan tidak terjadi. Hal ini dikarenakan mekanisme pemilihan perwakilan yang dilakukan pedagang adalah mekanisme struktur lama (patriarki) dimana laki-laki dianggap lebih memiliki kapasitas untuk mengurusi urusan publik.

\section{Tantangan Peran Organisasi Perempuan dalam Proses Resolusi Konflik dan Perubahan Sosial.}

Demokrasi lazimnya ditandai dengan keaktifan organisasi masyarakat sipil dalam memperjuangkan hak-hak masyarakat. Kondisi minimnya peran perempuan dalam proses 
resolusi konflik secara formal dan kekerasan yang dialami perempuan dalam konflik pada masa reformasi ini memunculkan pertanyaan mengapa organisasi yang fokus terhadap isu perempuan di Kota Padang tidak ikut berperan dalam permasalahan ini. Organisasi masyarakat sipil yang diharapkan ini diantaranya adalah LSM Nurani Perempuan dan Organisasi Bundo Kanduang Kota Padang.

LSM Nurani Perempuan ini tidak melakukan upaya intervensi karena isu perempuan dalam konflik ini tidak cukup menjadi isu krusial di kalangan pihak-pihak yang terlibat, isu perempuan dikalahkan dengan isu konflik itu sendiri, padahal LSM sadar betul bahwa isu keadilan gender harus selalu disandingkan dengan isu apapun.

“.....dalam permasalahan ini kekerasan terhadap perempuan tidak menjadi fokus bagi laki-laki itu sendiri. Isu perempuan itu menjadi lepas, sedangkan kami sendiri tidak begitu intens untuk mendampingi...Kami terbatas, kalau harus bolakbalik ke sana, jika PBHI itu kan jaringannya banyak...Banyak tantangan kami untuk masuk ke situ, mungkin kawan-kawan itu sendiri belum merasakan persoalan (gender) yang penting yang harus diantisipasi bersama. Padahal kita bisa bekerja sama...Dampak konflik yang paling terasa itu kan bagi perempuan karena pedagang mayoritas kan perempuan.." (Wawancara dengan Yefri Heriani, Ketua LSM Nurani Perempuan, 7 Oktober 2012 di Kota Padang)

Hal ini membuat LSM ini kalah untuk menyuarakan keadilan terhadap perempuan, terutama perlindungan terhadap perempuan yang menjadi kekerasan aparat keamanan negara pada saat puncak konflik berlangsung. LSM ini sempat melakukan diskusi untuk melakukan pemetaan konflik yang terjadi, namun ketika keberlanjutannya akan didiskusikan, isu tersebut menguap dengan sendirinya.

Satu-satunya organisasi yang kental dengan budaya Minangkabau adalah organisasi Bundo Kanduang. Organisasi ini diharapkan sebagai ruang negosiasi bagi perempuan untuk mencapai kepentingannya. Namun sangat disayangkan Kegiatan-kegiatan organisasi ini terbatas pada simbol-simbol budaya dan cenderung tidak menyentuh substansi keadilan hak-hak bagi perempuan. Buktinya, intervensi organisasi Bundo Kanduang sama sekali tidak terdengar pada permasalahan konflik Pasar Raya ini, padahal dampingan organisasi ini sangat penting untuk melindungi perempuan dari kekerasan dalam konflik serta melakukan upaya untuk mengikutsertakan perempuan dalam proses pengambilan keputusan pada resolusi konflik.

Paradigma organisasi merupakan tantangan yang besar untuk membongkar sistem yang mengukung dan merugikan sesama perempuan itu sendiri. Tantangan organisasi justru terletak pada kerangka berpikir yang cenderung ingin mempertahankan sistem yang baku dan menolak perubahan ke arah yang lebih baik. Oleh karena itu dibutuhkan kesamaan nilai dan tujuan serta mampu bekerja sama dalam menyusun strategi dan bertindak. Jika hal itu telah terlaksana, maka semua pihak dipastikan mendapatkan manfaat yang adil dan seimbang dalam berbagai sektor kehidupan. Namun untuk memperjuangkan hal ini, tentunya tidak dapat hanya didasarkan dari perspektif perjuangan perempuan itu sendiri saja namun juga harus didukung oleh relasi gender nya yaitu laki-laki untuk ikut melakukan perubahan.

\section{Kesimpulan}

Kesenjangan peran perempuan dalam proses resolusi konflik rehabilitasi dan rekonstruksi Pasar Raya Padang deiartikan sebagai peran aktif perempuan dalam setiap proses resolusi konflik, namun kenyataannya peran perempuan sangat kecil pada proses resolusi konflik ini. Tindakan kolektif yang dilakukan perempuan sebagai bentuk peran menuju proses resolusi konflik justru membawa perempuan sebagai korban kekerasan. Namun, ketika proses resolusi konflik secara formal dilakukan melalui perundingan, perempuan tidak lagi berperan dan mengikuti proses tersebut. 
Sistem Matrlineal disandingkan dengan struktur politik patriarki dalam budaya Minangkabau. Keutamaan laki-laki sebagai perwakilan urusan publik dan pemimpin sebuah organisasi diterapkan oleh pihak yang terlibat sehingga mempengaruhi minimnya peran perempuan dalam proses resolusi konflik ini. Struktur politik demokrasi diterapkan oleh aktivis perempuan yang berperan sehingga membuatnya menjadi agen yang aktif pada masa terjadinya konflik, namun tidak cukup membuatnya berperan aktif dalam proses perundingan secara formal. Penyebabnya adalah aktivis perempuan tersebut terkendala dengan indikator kapasitas sumber daya manusia yang dituntut dalam kompetisi terbuka pemilihan perwakilan perundingan.

Beradasarlkan hasil studi ini, penulis menyarankan, pertama agar rekonstruksi sosial mengenai dikotomi peran gender dalam ruang publik maupun ruang privat (domestik) dapat dimulai dengan penyebaran pengetahuan yang maksimal kepada masyarakat. Kedua Pengarusutaman gender diperlukan pada setiap isu dan potensi organisasi masyarakat sipil dapat dimaksimalkan untuk melakukan upaya ini.

\section{Kepustakaan}

Coser, Lewis. 1967. Continuities in the Study of Social Conflict. New York: The Free Press.

Emilia, Ranny. 2008. Studi Konflik dan Perdamaian : Memperbaiki Dunia Melalui TanganTangan Perempuan. Padang: Program Studi Ilmu Hubungan Internasional Universitas Andalas.

Jendrius. 2012. "Keterlibatan Perempuan dalam Politik di Nagari." Makalah disajikan pada Seminar Perempuan, Ruang Publik \& Islam, Padang, 9 Oktober 2012.

Jhonson, Doyle Paul 1986. Teori Sosiologi: Klasik dan Modern II. Terj. Robert M.Z. Jakarta: PT. Gramedia Pustaka Utama.
Lampong, Sri, R. D. 2008. "Peran Perempuan dalam Resolusi Konflik (Studi Tentang Konflik di Maluku)." Tesis Tidak Dipublikasikan. Fakultas Ilmu Sosial dan Politik: Universitas Gadjah Mada.

Miles, Matthew dan A. Michael Huberman. 1992. Analisis Data Kualitatif. Jakarta: Universitas Indonesia Press.

Ritzer, G. dan Douglas J. Goodman. 2005. Teori Sosiologi Modern. Jakarta: Prenada Media.

Satriyati, Ekna, 2008. "Women and Peace: The Role of Dayak and Madurese Woman in Resolving Conflicts between Dayak and Madurese Ethnics in Central Kalimantan," dalam Woman in Public Sector (Perempuan di Sektor Publik). S. H. Sastriyani (Eds). Yogyakarta: Pusat Studi Wanita Universitas Gadjah Mada.

\section{Internet:}

"Perempuan Pada Meja Perdamaian Indonesia: Meningkatkan Kontribusi Perempuan dalam Penyelesaian Konflik," Laporan dari Centre for Humanitarian Dialogue dan Lembaga Ilmu Pengetahuan Indonesia. tersedia di http://www. hdcentre.org/files/Report\%20WOAI\%20 081110.pdf. diakses 8 Mei 2012. 
